\title{
Sexual Markets or Black Markets? Gendered Technologies of Extraction and Redistribution among Young Men and Women in an African City
}

\author{
Christian Groes-Green \\ Roskilde University, Denmark
}

\begin{abstract}
This article addresses the everyday technologies of 'extraction and redistribution' that young women and men use in order to adapt to a situation of increasing unemployment in Maputo, Mozambique and other African cities. In this neoliberal economy informal and illicit trade with sex, stolen goods and counterfeit products are on the rise and the article shows how technologies of survival are highly gendered and reconfigure masculinities and femininities. In this article I argue that technologies of survival in urban Africa are based on logics of extraction-of money, goods and other valuables from the well off - as an alternative to wage labor, salaries and more respected sources of income and redistribution of incomes to kin and social networks. Technologies of extraction are highly gendered and a division of "informal labor" exists in this shadow economy where many young women enter into transactional sex with sugar-daddies, called sponsors or patrons, who provide for them in exchange for sex while male peers often become street vendors, street artists or petty criminals engaged in the so-called 'black' markets of theft, sale of counterfeits, and circulation of stolen goods, alcohol and drugs. As I show, these gendered markets are highly entangled and interdependent, and as I argue, male and female markets use many of the same technologies, sources and circuits of exchange.
\end{abstract}

Keywords:Youth, everyday technologies, unemployment, illicit economies, gender

\section{Introduction}

In this article, I address technologies of survival among young women and men in the city of Maputo, in Mozambique, technologies which I argue, are perhaps best captured by the concepts of extraction and redistribution.

In Maputo, where I have done field research since 2007, young people experience the harsh effects of neoliberal reforms and a rising inequality between the haves and the have-nots. The combination of poverty, growing unemployment and lacking educational opportunities, in post-socialist Mozambique, have in different ways pushed young women and men into an informal economy where sex trade and trade with illicit goods have become some of the only avenues to survival, and social or geographical mobility as well as to recognized manhood and womanhood. In this article, I argue that such technologies for survival in urban Africa are based

Christian Groes-Green, Ph.D, Associate Professor, Department of Culture and Identity, Roskilde University.

Correspondence concerning this article should be addressed to Christian Groes, c\% Ramati. Sønder Boulevard 109, st th 1720 Kbh V. E-mail: cgroes@ruc.dk. 
on logics of extraction — of money, goods and other valuables from the well off—as an alternative to wage labor, salaries and more respected sources of income. Technologies of extraction are highly gendered and a division of "informal labor" exists in this shadow economy where many young women enter into transactional sex with sugar-daddies, in Mozambique called sponsors or patrons, who provide for them and give them money and gifts in exchange for sex. In Maputo, women who enter the sexual economy to look out for sponsors are called curtidoras (women who celebrate, cultivate life). This notion connotes fun, luxury and getting most out of life, socially and economically. By contrast, many young men become street vendors, street artists or petty criminals engaged in the so-called "black" markets of theft, production and sale of counterfeits, circulation of stolen goods, bootlegging and drug trade. Yet, as I show, these gendered markets are highly entangled and interdependent, and as I argue, male and female markets use many of the same technologies, sources and circuits of exchange.

I will present three interrelated arguments. Firstly, I will present some reflections about the exclusion of youth from the space of work and education to spaces of non-work and fields of extraction, something the writer illustrates with notions and experiences from the field. Secondly, I will show how this change has affected young men and women differently in Mozambique and elsewhere in Africa and how it has transformed ideals and enactments of masculinity and femininity. Finally, I will discuss the transformative role of youth when they face unemployment and inequality. This analysis is based on ethnographic fieldwork and interviews with more than 50 young men and women, some of whom the writer has known for several years and on interviews with their families and sex partners.

\section{Exclusion from Spaces of Work to Fields of Extraction}

From all over Africa, scholars have reported how youth in the absence of work, seek out alternative sources of income for themselves and their families. This affects their ability to become respected members of society, their ability to marry and to reach adulthood. As Alcinda Honwana (2013) recently said: "Many men are unable to attain the prerequisites of full adulthood and take their place as fully-fledged members of society". She shows how youth are stalled in this new economy, trapped in what she calls waithood, a prolonged period of suspension between childhood and adulthood, waiting to become accepted. These young Africans constitute a majority, which is excluded from the job market and the political system. Daniel Mains (2007) depicts unemployed young men in Ethiopia who pass time imagining being Hollywood actors in another time and space, where they are respected and have human value. I met many youngsters in Maputo who waited for the times to change, standing on the street corner, drinking beer, playing ball, imitating TV stars, telling jokes and seducing the opposite sex. Waiting for a day when the tide would turn and a better life would materialize. So I will not deny that many youngsters are indeed trapped in waithood. Yet, the focus of this article is on those youngsters who are tired of waiting, who will not accept being excluded from the labour market, or reduced to human waste, as one informant put it.

In Maputo, people differ between work (trabalho) and "making a living” (desenrascar a vida). "Making a living” refers to income-generating activities that are outside the waged labor market. During the writer's time, hanging out with young men and women in the poor suburbs of Maputo, metaphors of extraction were widely applied to describe what "making a living" entails: Young women talk about senguer, the word meaning "to milk the cow". In Changana, this word refers to the practice of seducing men to give money and gifts. Even the sexual act itself is talked about in terms, such as "milking” or "sucking” money out of men, or "pumping” them 
for gifts. Others talk about "drawing out” money from men ("tirar dinheiro”), or about pulling men and "putting them in the bottle". In Malawi, women use metaphors, such as "skinning the goat", in South Africa, they talk about "drinking men's money". All of these expressions point to gender-specific practices of extraction, where women convey the image of a forager or hunter and rich men are blossoming fields or wounded animals. As people shall see, it is not as simple as that. Men use similar metaphors, but they often put more emphasis on their ability to deceive, partners, friends or customers. Sasha Newell (2009) talks about young people in Abidjan, Cote D’Ivoire "bluffing”, tricking and exploiting intimate relationships for material gain, Henrik Vigh (2006) describes the "social navigation" of young men in Guinea-Bissau, who improvise in their search for immediate satisfaction of needs. In her studies from Tunesia, Mozambique and Senegal, Alcinda Honwana (2003) refers to Claude Levi-Strauss' concept of the bricoleur, "the jack of all trades" who manipulates circumstances to attain his/her own ends.

What I argue here is that technologies of extraction become significant when no legitimate form of work or source of income is available, and at a time when education does not give access to jobs. I further argue that extracted values constitute the basis for redistribution at a time when no institutions, in particular the state, are able to support the poor. Large portions of the money that young people are able to extract end up in the pockets and households of economically disempowered family members, friends and neighbors.

The metaphors of extraction the writer mentions here can also be seen as a parody of and a reaction to Western colonial and postcolonial powers' extraction of natural resources, like timber, oil, coal, nuts and vegetables from the country's soil, or refer to foreign investors in business projects who take their profits with them home, and companies importation of foreign labor instead of employing Mozambicans. As a female sex trader put it bluntly, referring to her "milking" of a Portuguese sponsor: "These Portuguese have been screwing us over so many times, it is really my time to screw them over". Others refer to the injustice of a political system of corruption and inequality. A male informant, selling bad quality drugs and stealing from "rich kids", argued that: "The politicians and rich folks have been exploiting our ass for so long, robbing their own people, now it's our turn to take something back".

It is not only young men and women who use metaphors of extraction: Women's sponsors complain about the immoral and cynical aspects of the sex trade: They condemn women's practices of seduction and trickery, accusing them of being leeches, parasites, money sick or coup makers. By contrast, curtidoras call sponsors their ATMs, and believe it is their right to draw money out of men. Such disagreements about licit and illicit means of extraction and expropriation reveals opposing perspectives related to gender, generation and social class. It would be a mistake, though, to conclude that sexual relationships described above are devoid of love and devotion. Emotional aspects are not easily distinguished from monetary aspects; love and deception go hand in hand.

Despite significant differences, there are also similarities between what young men and women do "for a living”: Both move from the poor suburbs into Maputo city in order to extract value from the local middle class, and the elite as well as from European expats. They seduce people with money, invest in relationships, use all efforts to obtain values, and take home whatever surplus they may have extracted at the end of the day. These are examples of young people trying to adapt to a changing economy and insisting to become part of it. Extraction, I argue, is a "state of being" and "becoming" in an economy, where sexual markets and informal black markets are blossoming, while the "legal" and "formalized" markets become ever more exclusive and impenetrable, protected by the state and big companies, unable or unwilling to create formal channels of 
redistribution. Now, this dichotomy is perhaps too simple. Boundaries between formal and informal markets, between extraction and work or waged labor are not always easy to draw and they quite often become blurred. Thus, I use these concepts in a metaphorical sense, rather than as rigid sociological categories.

\section{Gendered Technologies: Reconfiguring Masculinities and Femininities}

So what characterizes these technologies of extraction and how are they gendered? First and foremost, they are technologies of the body, and the body's attraction, appearance and seduction of others. But they also draw on material technologies, including the appropriation, use and exchange of items, such as mobile phones, cameras, computers and access to Internet.

Among young men, technologies of the body become a key to achieving a sense of manhood in relation to other men and female partners. In an urban landscape, where men are deprived of access to work and stable incomes, and thus unable to live up to the breadwinner ideal, young men tend to become reduced to their bodily qualities and powers. A large number of young men base their authority vis-à-vis women on sexual performance, bodybuilding and use of aphrodisiacs to be good lovers. The breadwinner ideal, which they claim used to be attainable for a larger segment of men, is harder to live up to as unemployment deepens after national companies have closed, and work in South African mines is no longer an option as it is used to be. While young men from the city's growing middle class enact hegemonic masculinities in relationships to female partners, by means of financial powers, higher education and adherence to the "breadwinner" ideal, poor young men react to unemployment by enacting masculinities that are subordinate vis-à-vis middle class peers, but which still seek to impress women through what Reawyn Connell (2003) calls "protest masculinities".

In the absence of legal access to status items, young men find other ways of acquiring what they need to be seen as real men: Besides training their bodies and boosting their sex drive, many also cross the line into the underworld of theft, counterfeiting, buying and selling stolen goods, gambling and tricking people. In recent years, the writer has noticed how young men join a growing small-scale industry of duplication, production and sale of counterfeit products, such as, videos and CDs. I also met young men who stole cars, mobile phones and cameras, or who sold them at the local black market in an urban zone called "Columbia" -infamous for its drug trade and crime. Young men in the illicit economy are often referred to as or call themselves moluwenes (marginals, bad boys). These men did not see themselves as criminals, but believed they did the only right thing at a time when clearly the government did not live up to its promises of work, education and progress for youth. As 26 years old Antonio said:

"Now I have a car, because I found a way to get it myself. There is no other way up. When I go to the restaurant, the women see me, they adore me. I might get caught stealing one day, but right now I'm a real man”.

Antonio's story illustrates that when the future does not hold any promise, living in the moment and acquiring goods easily become defining traits of young masculinities. Uses of phones and Internet are also key features of this economy, and one's ability to master such technologies is a vital source of respect from peers.

Obviously, the informal economy is much more than criminal activities. Many men go to the street to sell fruit and vegetables, nuts and handicrafts or clothes on local markets. This is another example of the way gender is reconfigured in Maputo. For a long time, street vendors were women, and selling goods on the street was seen as a feminine activity, not unlike prostitution because it entailed the public seduction of costumers (Sheldon, 2003). As men enter this market, their self-perception changes, and so do notions of what is male and 
female. Nevertheless, the world of crime and toughness offers men a version of manhood that they feel it gives them more respect as well as access to consumer goods and women.

Young women seem to adapt to this transforming economy in a different way. Much research suggests that the sexual economy, including transactional sex, sex work, and strip clubs are on the rise, not only in Maputo, but across urban Africa. Curtidoras exploit the great demand for sex and pleasure among the city's wealthy men, and use the city's vibrant nightlife and international atmosphere as a platform for their extractive endeavors. The demand for sex and young lovers has only intensified with the influx of Europeans, working there as developments workers, business people or diplomats, which has paradoxically helped create one of the main sources of income for poor women. The great amount of capital from new businesses, UN salaries, NGOs and embassies are spent on entertainment, leisure, technology, hedonistic consumption and sex. At night, streets in downtown Maputo are packed with sex traders, escorting foreigners and the well off to restaurants, bars, discos, casinos and beach resorts. The amount of money women can get out of these relationships is much higher than any "normal job", and as the writer's most recent research shows, liaisons with foreigners can also become a ticket out of Mozambique, to a better life in Europe or South Africa. The human costs can be severe, as sex trade is illegal and condemned, and since unsafe sex is common, there is a great risk of contracting HIV and AIDS. Yet, the women that I interviewed often saw the sex trade as beneficial and empowering, and some even believe they have the upper hand vis-à-vis sponsors. I realized that they actively use eroticism and sexual power to seduce men, and play tricks that make men emotionally dependent on them, so they will provide for them. This is the practice referred to as "putting men in the bottle". Women exchange knowledge of how to flirt and seduce, they exchange bedroom skills and how to use of intimate parts to satisfy men and make them "go crazy”, as they say. They also discuss appearance and how to dress well, make new hairstyles, use body creams and make up. Curiously, female kin often plays a central role in "putting men in the bottle", including giving advice on how to seduce men through conversation, how to control them in bed and attach them emotionally. Intergenerational alliances are not only formed with female kin, but also with female curandeiras, the local healers who supply women with magic herbs and creams, and who provide secret tricks about casting spells on a desired man. As I argued with, regard to the young men, the body seems to become the primary tool, resource and capital for women when other sources of power crumble (Groes-Green, 2011). So the curtidoras identity is one among new femininities emerging as women begin to redefine themselves, and reject the ideals of motherhood and marriage at an early age, instead finding various sponsors, who ensure them relative economic independence.

What this example also shows is that how technologies of extraction are formed in and through female spaces. There has been a lack of attention to women's eroticism as a collective power, as also Audrey Lorde reminded people. As postcolonial feminists, like Sylvia Tamale and Oyeronke Oyewumi have argued, the power and agency of the female body have been neglected in Western feminism, and in particular, the role of eroticism plays in societies where men have the upper hand in economic and political terms. So merely seeing these women as victims of sexual commoditization, they do not do justice to their creative adaption and resistance towards a situation of non-work and waithood. They exemplify a transformation of what it means to be a young woman.

Technologies of extraction also include modern technologies, such as, mobile phones, cameras and the Internet. Women in the sex trade go to Internet cafes to upload sexy and enticing pictures to their dating 
profiles and facebooks, where they attract new sponsors and sex customers. Mobile phones play a central role as a tool for managing sexual relationships. Much flirting and planning of erotic encounters takes place through mobile phones, sending messages, photos, numbers, and asking sponsors to send airtime.

However, people also need to understand how technologies of extraction help sustain the broader community. I found that a large percentage of the money curtidoras earn are distributed to kin, primarily to mothers and aunts, who then redistribute to siblings, and male family members, with little or no income. In general, the activities of young women, as well as young men, are not merely for personal profit: They serve a socio-economic function, which the state and market cannot provide: survival and security. This is why suburban communities and beneficiaries tolerate illicit practices. But these practices are only accepted when carried out far away in the city center and vis-à-vis the affluent and foreigners. Theft, trickery, deception and prostitution are strongly condemned and punished within suburban communities.

Another point I want to make is that incomes from transactional sex or trickery are used for more than survival. They are often invested in small business or property. Every so often, I saw curtidoras giving mothers or brothers money to build a chicken farm or a beauty shop, and I saw young women themselves buying land or constructing a house in order to live from renting it out. So entering sexual markets or black markets is not a one-way street: Many end up leaving illicit trades, doing legal business and investments that ensure a stable income and a sense of long term security for themselves and their kin. Thus, over time they themselves become sponsors for families and communities, which wins them status and respect.

Yet, it is not only households and kin that depend on women's sex trade, male peers also benefit as partners, boyfriends or friends. In fact, the sexual market and the black market, dominated by males and females respectively, are in many respects entangled and interdependent: The men provide clients, transport, access to computers, cheap drugs and alcohol when curtidoras ask for it, while curtidoras provide costumers, loans and knowledge about clients for counterfeiters, tricksters and thieves. Another example of transforming gender roles is that an increasing number of young men begin selling sex to local men or foreigner or look for white expat women, who can support them. So although the technologies of extraction are highly gendered, they are also becoming more entangled and overlapping.

\section{Conclusion}

Do these young men and women and their extractive technologies hold any promises for the future? Perhaps because they are seen as illegitimate and a threat to stability and formal labor markets, both female and male sectors of the illicit economy are condemned by the elite, the media and politicians waging a war against crime, drugs, counterfeits, unauthorized street vending, and against prostitution, moral decay, indecent sexual behavior in public, and what a member of parliament called "young women's abuse of honest members of society”. But instead of condemning extractive practices, people should perhaps see them as signs of the great potential of a generation that is able to adapt and be creative in the face of radical transformations. Extractive technologies do not merely express self-interest, disorder and destruction. At the end of the day, they may also be seen as collective efforts to redistribute resources, reinstall justice, recreate social order and redefine gender roles of young women and men. 


\section{References}

Agadjanian, Victor. (2005). Men Doing “Women’s Work”: Masculinity and Gender Relations among Street Vendors in Maputo, Mozambique. African Masculinities: Men in Africa from the Late $19^{\text {th }}$ Century to the Present. Lahoucine Ouzgane., \& Robert Morrell. ( Eds.), (pp. 257-270). New York: Palgrave Macmillan.

Arnfred, S. (2011). Sex, Food and Female Power. Sexuality and Gender Politics in Mozambique: Rethinking Gender in Africa. Signe Arnfred. (Ed.), (pp. 165-187).Woodbridge, UK: James Currey.

Bloch, Maurice., \& Jonathan Parry. (1989). Money and the morality of exchange. Maurice Bloch and Jonathan Parry (red): Money and the morality of exchange. (pp. 1-33). Cambridge: Cambridge University Press.

Cole, Jennifer. (2004). Fresh Contact in Tamatave, Madagascar: Sex, money and intergenerational transformation. American Ethnologist, 31(4), 573-588.

Connell, Raewyn. (2003). Masculinities. Oakland, CA: University of California Press.

Groes-Green, Christian. (2013). To put men in a bottle: Eroticism, kinship, female power and transactional sex in Maputo, Mozambique. American Ethnologist, 40(1), 102-117.

Groes-Green, Christian. (2011). Philogynous Masculinities: Contextualizing Alternative Manhood in Mozambique. Men and Masculinities, 15(2), 91-111.

Groes-Green, Christian. (2010). Orgies of the moment: Bataille’s anthropology of transgression and the defiance of danger in post-socialist Mozambique. Anthropological Theory,10(4), 385-407.

Hanlon, Joseph. (2010). Mozambique: The War Ended 17 Years Ago, but We Are Still Poor. Conflict, Security and Development, 10(1), 77-102.

Hawkins, Kate., Kirstan Price., \& Fatima Mussa. (2009). Milking the Cow: Young Women’s Construction of Identity and Risk in Age-Disparate Transactional Sexual Relationships in Maputo, Mozambique. Global Public Health, 4(2), 169-182.

Honwana, Alcinda. (2013). Youth, waithood, and protest movements in Africa. A key note lecture at the Fifth European Conference on African Studies. Lisbon.

Leclerc-Madlala, Suzanne. (2003). Transactional Sex and the Pursuit of Modernity. Social Dynamics, 29(2), 213-233.

Maganja, Richard K., Susanne Maman., Allison Groves., \& Jessie K. Mbwambo. (2007). Skinning the Goat and Pulling the Load: Transactional Sex among Youth in Dar es Salaam, Tanzania. AIDS Care, 19(8), 974-981.

Mains, Daniel. (2007). Neoliberal times: Progress, boredom, and shame among young men inurban Ethiopia. American Ethnologist.,34(4), 659-673.

Newell, Sasha. (2009). Godrap Girls, Draou Boys, and the Ivoirian Sexual Economy of the Bluff. Ethnos, 74(3), 379-402.

Oyewumi, Oyeronke. (2002). Conceptualising Gender: Eurocentric Foundations of Feminist Concepts and the Challenge of African Epistemologies. Jenda, 2(1), 1-23.

Sheldon, Kathleen. (2003). Market and Gardens: placing Women in the History of Urban Mozambique. Canadian Journal of African Studies, 37(2-3), 258-295.

Tamale, Sylvia. (2006). Eroticism, Sensuality and “Women’s Secrets” among the Baganda. IDS Bulletin, 37(5), 89-97.

Vigh H. (2006). The colour of destruction: On racialization, geno-globality and the social imaginary in Bissau. Anthropological Theory, 6(4), 481-500.

Wojcicki, Janet, M. (2002). She Drank his Money: Survival Sex and the Problem of Violence in Taverns in Gauteng Province, South Africa. Medical Anthropology Quarterly, 16(3), 267-293. 